\title{
A Study of Fashion Brand Experience and Consumer Behavior
}

\author{
${ }^{1}$ Jaemin LEE \\ 1. First Author \& Corresponding Author Ph.D Student, College of Business, SungKyunKwan University, Korea. \\ Email: gregfoster@hanmail.net
}

Received: April 19, 2020. Revised: May 06, 2020. Accepted: May 06, 2020.

\begin{abstract}
The purpose of this study was to empirically investigate the relationship among fashion brand experience, brand loyalty, relationship quality, and repurchase intention. The 420 survey questionnaires were distributed among the consumers in their 30s and 40s who had experience buy fashion brands products through convenience sampling in Seoul. Due to the reliability of data, 120 samples were discarded and 300 samples were put to actual analysis. By using SAS 9.4, data were analyzed for frequency analysis, reliability analysis, correlation analysis. The results of the study are as follows. First, the fashion brand experience which is consist of sensory, affective, behavioral and intellectual experience had positive effects on brand satisfaction and brand trust. Second, brand trust and brand commitment and the relationship quality of brand satisfaction, only satisfaction and commitment affects brand loyalty significantly. Lastly, brand loyalty had significantly effect on repurchase intention. It presented the potential to use the brand as a strategic tool to build strong brand assets, along with providing specific ways to secure differentiated competitiveness in the fashion brand market. It is also thought to be meaningful in that we presented a practical strategy to build and strengthen a lasting bond with consumers by looking at the impact on the quality of the relationship.
\end{abstract}

Keywords: Fashion Brand Experience, Brand Loyalty, Relationship Quality, Repurchase Intention, Brand Trust

JEL Classifications: M30, M31

\section{Introduction}

\subsection{Necessity of Research}

The importance of the brand is increasingly emphasized as a strategic corporate asset that can secure a sustainable competitive advantage through differentiation from rivals in a fierce market competition environment. In particular, as technological differences between products to meet the needs of diversified consumers and similar products continue to be released, functional quality alone, the primary attribute of the product, has faced limitations in satisfying 
consumers. Companies recognize the establishment of differentiated brand assets as essential elements for securing the core competency of the company and long-term corporate survival, and implement systematic and strategic brand management to enhance corporate competitiveness and improve performance.

\subsection{Purpose of Research}

Research on brand experience has been made in a variety of fields. However, research that verifies the effectiveness of the experience in terms of fashion brands is still considered to be incomplete. Therefore, research to identify consumer behavior based on fashion brand experience is judged to contribute positively to drawing out the measures necessary for brand management. For this reason, this study is primarily aimed at predicting consumer behavior by applying brand experience to fashion brands to identify the quality of fashion brand experience and relationship, brand loyalty and relationship with intent to repurchase.

\subsection{Relationship Between Fashion Brand Experience and Quality of Relationship}

First, if you look at the prior studies on brand satisfaction among the quality factors of the fashion brand experience and relationship, it is as follows. A study by (Wang, 2010) reveals that positive brand experience affects brand satisfaction, while a study by (Kaufmann, et al, 2016) revealed that brand experience affects consumer satisfaction. It also claimed that (Wang, 2010) experience with green brands, which are related to environmental protection, affects customer satisfaction. These prior studies can be said to be a test of the specific influence of brand experience on satisfaction. Based on these results, it is judged that the following assumptions can be derived:

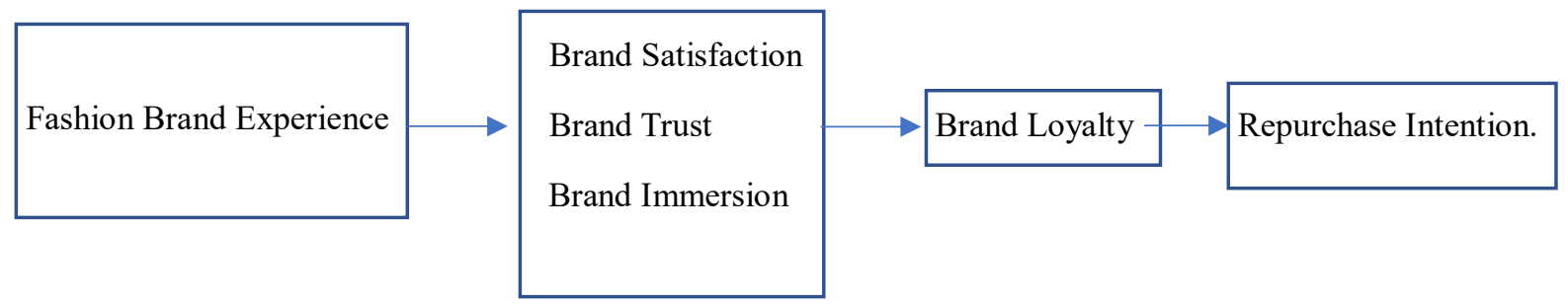

Figure 1: Research Model

H1: Fashion brand experience will have a significant effect on brand satisfaction among quality factors in the relationship.

Second, if you check the leading studies on brand trust among the quality factors of fashion brand experience and relationship between (Hicks, 2013) the restaurant's sense, sensibility, and cognitive experience factors showed significant relationship to brand trust, and (Otubanjo et al., 2010) study said that sensory experience and cognitive experience, the sub-factors that make up the brand experience, have a positive effect on brand trust. These existing preceding research results verify the influence between brand experience and brand trust. Therefore, the following assumptions were derived based on these grounds.

H2: Fashion brand experience will have a significant effect on brand trust among quality factors in the relationship.

Third, among the quality factors of the experience and relationship of fashion brands, the hypothesis is as follows. Schimmelpfennig and Hollensen (2013) study said that emotional, cognitive, and behavioral experiences among the factors experienced by mobile brand applications have a significant impact on brand immersion, and if you look at the research by (Hicks, 2013) the experience of leading fashion brands has a positive effect on consumers' immersion in 
stores, you can identify the relationship between brand experience and trust. It is judged that the following hypotheses can be derived from the specific basis of the preceding studies that examined the relationship between brand experience and brand immersion.

H3: Fashion brand experience will have a significant effect on brand immersion among quality factors in the relationship.

\subsection{Relationship Between Quality of Relationship and Brand Loyalty}

First, if you check the relationship between brand satisfaction and brand loyalty among quality factors by Schimmelpfennig and Hollensen (2013) also revealed that the satisfaction of the brand of the fashion goods has a significant impact on brand loyalty, and that Lee Jung-min is believed to be the theoretical basis of the research theory that the brand loyalty was influenced by (Otubanjo et al., 2010) specialty. Based on the basis of these preceding studies, the following hypotheses were derived:

H4: Brand satisfaction among the quality factors of the relationship will have a significant effect on brand loyalty.

Second, if you check the relationship between brand trust and brand loyalty among quality factors a study by Korea and the U.S. found that brand trust had a significant impact on brand loyalty, a study by (Kaufmann, et al, 2016) said brand trust has had a positive influence on brand loyalty, and a study by (Mann, 2013). Based on prior studies that reveal a significant relationship between brand trust and brand loyalty, the following research theories can be derived.

H5: Brand trust among the quality factors of the relationship will have a significant effect on brand loyalty.

Third, if you check the relationship between brand immersion and brand loyalty among quality factors a study by (Kaufmann et al., 2016) found that brand trust by fashion brand experience marketing activities affected brand loyalty, and (Mann, 2013) research shows that brand immersion has a significant effect on brand loyalty. Thus, on this basis, the following hypotheses were derived:

H6: Brand immersion among the quality factors of the relationship will have a significant effect on brand loyalty.

\subsection{Relationship Between Brand Loyalty and Intent to Repurchase}

Brand loyalty, as a result of looking at prior studies to understand the relationship with the intention of repurchase, indicated that brand loyalty in research related to (Marti-Parreno et al., 2013) restaurant brand had a positive effect on the intention of repurchase, and Royand Moorthi (2012) study said that brand loyalty at clothing shops had a significant effect on the intention of repurchase. In addition, a study by (Marti-Parreno et al., 2013) revealed that brand loyalty has a significant effect on the intention of buying again. The following hypotheses were derived from these grounds:

H7: Brand loyalty will have a significant effect on the repurchase intention.

\section{Research Method}

\subsection{Subject to Study}


This study was conducted on consumers with repurchase experience and using fashion goods. Specifically, the study selected young people in their $30 \mathrm{~s}$ and $40 \mathrm{~s}$ as subjects of the study, which was selected as appropriate because Schimmelpfennig and Hollensen (2013) stated that consumers of younger age had a relatively higher understanding of the brand and a higher interest in it compared to other age groups.

\subsection{Measuring Tools}

Questionnaires were used as a tool to achieve the objectives of this study, and the questions used in the survey were constructed appropriately for the purpose of this study, which was used in previous preceding studies. All of the concepts presented in this study are based on prior studies related to the brand experience, consisting of seven levels from 1 to 5 on a five-point scale. Based on Roy and Moorthi (2012), the questions used as four sub concepts of sensory, emotional, behavioral and intellectual experience were modified and supplemented to fit this study and composed of a total of 42 questions. The quality of a relationship is an important concept used to represent a relationship with a customer in marketing, and satisfaction, trust and immersion are important components. Therefore, this study defined the dimensions that make up the quality of the relationship as satisfaction, trust and immersion and proceeded with the study. Based on (Marti-Parreno et al., 2013) the questions used by (Kaufmann, et al, 2016) were transformed into a total of five questions, and brand trust consisted of four questions by borrowing the questions used in (Mann, 2013).

\subsection{Data Processing}

This study selected a total of 300 samples as the final effective sample and conducted the study. Using SAS 9.4, frequency analysis was performed to identify demographic characteristics and reliability analysis was performed by calculating Cronbach's $\alpha$ coefficient to ensure internal consistency of measurement tools. Next, correlation analysis was performed to determine whether or not there is multiple coherence.

\section{Results}

\subsection{Correlation Analysis}

In order to identify the correlation between each variable set up in this study, the correlation between the variables was performed by calculating the Pearson equivalence correlation coefficient. The analysis showed that the correlation among all variables was statistically significant, and that the correlation coefficient was lower than .80 , so there was no problem of multiple coherency. Detailed analysis results can be found in Table 1.

Table 1: Feasibility Analysis

\begin{tabular}{|c|c|c|c|c|}
\hline \multicolumn{5}{|c|}{$\begin{array}{l}\text { Eigenvalues of the Correlation Matrix: Total } \\
=4 \text { Average }=1\end{array}$} \\
\hline & Eigenvalue & Difference & Proportion & Cumulative \\
\hline 1 & 2.28 & 0.76 & 0.56 & 0.57 \\
\hline 2 & 1.51 & 1.31 & 0.38 & 0.95 \\
\hline 3 & 0.20 & 0.19 & 0.05 & 1.00 \\
\hline
\end{tabular}




\begin{tabular}{|c|c|c|c|c|}
\hline \multicolumn{5}{|c|}{$\begin{array}{l}\text { Eigenvalues of the Correlation Matrix: Total } \\
=4 \text { Average }=1\end{array}$} \\
\hline & Eigenvalue & Difference & Proportion & Cumulative \\
\hline 4 & 0.01 & & 0.00 & 1.00 \\
\hline \multicolumn{3}{|c|}{$\begin{array}{l}\text { Squared Multiple Correlations } \\
\text { of the Variables with Each } \\
\text { Factor }\end{array}$} & & Cronbach Alpha Coefficient \\
\hline \multicolumn{2}{|c|}{ Factor1 } & \multicolumn{2}{|l|}{ Factor2 } & 0.88 \\
\hline \multicolumn{2}{|l|}{1.00} & 1.00 & & 0.91 \\
\hline & Factor1 & Factor2 & & 0.84 \\
\hline $\mathbf{X 1}$ & -0.50 & 0.02 & & 0.81 \\
\hline $\mathbf{X} 2$ & -0.10 & 0.55 & & 0.89 \\
\hline $\mathbf{X 3}$ & 0.52 & -0.08 & & 0.92 \\
\hline $\mathbf{X} 4$ & 0.00 & -0.51 & & 0.87 \\
\hline
\end{tabular}

\subsection{Suitability of the Research Model}

In this study, we wanted to check the quality of the brand experience and relationship, brand loyalty, and relationship with the intention of repurchase. Prior to verifying the research model, the four sub-factors of the brand experience were set as one measurement variable through a bundle of questions to proceed with the study. A group of questions is a method of reducing the number of measurement questions by combining multiple individual questions together or using the average value of the combined questions, assuming that the combined questions have a single dimension. The use of questionnaires can be more reliable and not only has a greater chance of following normal distribution, but also has the advantage of improved overall suitability of the model as individual questions are reduced. Thus, after analyzing the suitability of the research model by applying the method of this set of questions, it was determined that the model of this study met the suitability index and thus had no particular problem in conducting the study.

\subsection{Causality Analysis among Variables}

Table 2: Factor Analysis

\begin{tabular}{|c|c|c|}
\hline \multicolumn{3}{|c|}{ Factor Pattern } \\
\hline & Factor1 & Factor2 \\
\hline $\mathbf{X} 1$ & 0.85 & 0.50 \\
\hline $\mathbf{X} 2$ & -0.61 & 0.74 \\
\hline $\mathbf{X 3}$ & -0.80 & -0.60 \\
\hline
\end{tabular}




\begin{tabular}{|l|l|l|l|l|}
\hline \multicolumn{2}{|l|}{ Factor Pattern } & \multicolumn{2}{l|}{ Factor2 } \\
\hline \multicolumn{2}{|l|}{ Factor1 } & -0.61 \\
\hline X4 & 0.73 \\
$\begin{array}{l}\text { Variance Explained by Each } \\
\text { Factor }\end{array}$ & \multicolumn{2}{l|}{ Factor2 } \\
\hline Factor1 & 1.51 & X4 \\
\hline 2.28 & X2 & X3 & 0.91 \\
\hline Final Communality Estimates: Total = 3.79 & 0.99 & \\
\hline X1 & 0.92 & \\
\hline 0.98 &
\end{tabular}

\section{Discussion}

\subsection{Discussing the Quality of Brand Experience and Relationships}

The fashion brand experience, consisting of sensory experience, emotional experience, behavioral experience and intellectual experience, has shown significant influence on brand satisfaction and brand trust. (Hicks, 2013) said the brand experience has a positive effect on the brand's satisfaction, which is consistent with the results of the study, and Roy and Moorthi (2012) research suggests that the positive brand experience affects the brand's satisfaction, which can be used as grounds to support the results. In addition, Schimmelpfennig and Hollensen (2013) suggests that the brand experience of global fashion has a significant impact on brand trust, which is consistent with the results of this study, and (Wang, 2010) study shows that emotional experience, a sub-factor of brand experience, has had a significant impact on brand trust, which can be partially supported.

\subsection{Discussion of Quality of Relationship and Brand Loyalty and Intent to Repurchase}

First, fashion brand satisfaction has been identified as having a positive effect on brand loyalty. In a study related to brand experiences by (Marti-Parreno et al., 2013). Consumer satisfaction is said to have a significant impact on loyalty, and in a study on the experience of clothing shops by (Otubanjo et al., 2010). Customer satisfaction has a positive effect on brand loyalty. These prior studies are believed to help explain the discussion of the results of this study. What this study suggests is that consumers will be more loyal to the brand as a result if the various experiences offered by the fashion brand satisfy the needs they expect. In other words, it can be understood that if consumers have been compensated for their expectations of the fashion brand through the various empirical elements offered by the fashion brand, loyalty to having an ongoing relationship with the fashion brand is expressed. Thus, fashion brands need to use specific strategic measures to secure consumers' satisfaction and loyalty through the use of experience, and it is judged that they need to use product positioning strategies through market segmentation. This strategy is judged to be a practical enough strategy to understand what expectations and desires each consumer group has for the fashion brand and to elicit positive responses from consumers through the provision of appropriate products and services to that group. 


\section{Conclusions and Suggestions}

\subsection{Conclusion}

The purpose of this study is to look at the quality of brand experience and relationship, brand loyalty and relationship with intent to repurchase, and the study was conducted with a focus on fashion brands. There were selected as the main subjects for the study in 30s and 40s and using SAS 9.4, frequency, reliability and correlation analysis were conducted. The results of the study is the following. First, fashion brand experience has had a significant impact on satisfaction among the quality factors of the relationship, and second, it has been shown that the fashion brand experience has a positive effect on trust among the quality. Third, fashion brand experience has been found to have no effect on brand immersion among the quality factors of the relationship. Next, of the quality factors in the relationship, satisfaction has had a significant impact on brand loyalty, but it has been shown that trust does not affect brand loyalty. In addition, among the quality of relationships factors, immersion was found to lead to brand loyalty, and lastly, studies have shown that consumers' brand loyalty to fashion brands is a factor that can lead to re-buying of brands. This study is believed to be meaningful in that by applying the concept of brand experience to fashion brands, it presented the potential to use the brand as a strategic tool to build strong brand assets, along with providing specific ways to secure differentiated competitiveness in the fashion brand market. It is also thought to be meaningful in that we presented a practical strategy to build and strengthen a lasting bond with consumers by looking at the impact on the quality of the relationship.

\subsection{Suggestions}

This study conducted studies to suit the purpose and conducted a specific analysis to identify the quality of the fashion brand experience and relationship, brand loyalty and relationship with the intention to buy back and produce results. However, I would also like to suggest further research since this study also has some limitations. First, this study failed to verify the influence of individual factors by establishing brand experience consisting of sensory experience, emotional experience, behavioral experience and sub-factors of intellectual experience as one variable to identify the relationship quality, brand loyalty, and willingness to repurchase. Therefore, it will be meaningful to verify the influence of dependent variables on each sub-factor that constitutes a brand experience and compare and analyze the results of this study. Second, I think it is difficult to generalize the results acceptable to all age groups because this study limited the subjects to younger consumers in their 30 s and $40 \mathrm{~s}$. Therefore, it is deemed necessary to include all age groups in the study to proceed with the study.

\section{References}

Hicks, C. D. (2013). The future of sustainability-driven partnerships and a new role for brand strategy, Journal of Brand Management, 20(3), 259-260.

Kaufmann., \& Hans, R., \& Loureiro., \& Sandra, M. C., \& Manarioti, A. (2016). Exploring behavioral branding, brand love and brand co-creation, Journal of Product and Brand Management, 25(6), 519-523.

Mann, J. (2013). Being 'Brave': How Shire Pharmaceuticals nurtured its unique culture from a simple brand idea, Journal of Brand Strategy, 2(3), 239-241.

Marti-Parreno, J., \& Aldas-Manzano, J., \& Curras-Perez, R., \& Sanchez-Garcia, I. (2013). Factors contributing brand attitude in advergames: Entertainment and irritation, Journal of Brand Management, 20(5), 378-384.

Otubanjo, O., \& Abimbola, T., \& Amujo, O. (2010). Conceptualizing the notion of corporate brand covenant, Journal 
of Product and Brand Management, 19(6), 415-419.

Roy, S., \& Moorthi, Y. (2012). Investigating endorser personality effects on brand personality: Causation and reverse causation in India, Journal of Brand Strategy, 1(2), 169-175.

Schimmelpfennig, C., \& Hollensen, S. (2013). Celebrity endorsements: Exploring the processes for finding the right celebrity to endorse a brand, Journal of Brand Strategy, 2(4), 369-373.

Wang, H. M. (2010). Corporate social performance and financial-based brand equity, Journal of Product and Brand Management, 19(5), 338-342. 